Sains Malaysiana 50(9)(2021): 2641-2651

http://doi.org/10.17576/jsm-2021-5009-12

\title{
Antimicrobial and Antioxidant Potential of Methanolic Extracts from Different Parts of Stevia rebaudiana Bertoni Cultivated in Bulgaria
}

(Potensi Antimikrob dan Antioksidan Ekstrak Metanol daripada Bahagian Berbeza Stevia rebaudiana Bertoni Ditanam in Bulgaria)

\author{
Toncho DineV*, Milena Tzanova, Nikolina Rusenova, Neli Grozeva, Mariya Gerdzhikova \& Georgi \\ BEEV
}

\begin{abstract}
Stevia rebaudiana Bertoni is a plant species, which is frequently used not only as a sweetener, but also for its antibacterial and antioxidant properties. Nowadays, there are a large number of studies on the antimicrobial and antioxidant activity of $\mathrm{S}$. rebaudiana leaves, but there are almost no data about the antimicrobial and antioxidant potential of extracts from the other parts of $\mathrm{S}$. rebaudiana. The aim of the present study is to provide data of the antibacterial and antioxidant potential of methanolic extracts from different parts of S. rebaudiana (flowers, leaves, stems, rhizomes, and tubers) cultivated in Bulgaria. Antibacterial activity of the extracts against Staphylococcus aureus, Bacillus cereus and Escherichia coli was evaluated by agar well diffusion method, rutin content - by HPLC method, total phenolic content and radical scavenging potential - by UV-Vis analysis. S. rebaudiana extracts demonstrated antibacterial activity mainly against $\mathrm{S}$. aureus - flower extracts expressed the highest activity, followed by the leaf and stem extracts. Only flower and leaf extracts demonstrated very low antibacterial activity against B. cereus. S. rebaudiana extracts did not show any antibacterial activity against E. coli. Methanolic extracts of this plant are rich in antioxidants. The highest concentrations of rutin and total phenols were found in the rhizomes of the plants, followed by the leaves, tubers, flowers, and stems, which corresponded to the radical scavenging potential of the same plant part. Comparisons between Trolox equivalents and gallic acid equivalents in different parts of S. rebaudiana on one hand, and Trolox equivalents and rutin concentration on the other hand showed a positive dependence and high values of the Pearson correlation-0.9612 and 0.9707, respectively. The most important part of S. rebaudiana with medicinal significance (the leaves) has both comparatively good antibacterial activity and high antioxidant content, although the flowers and rhizomes expressed higher antibacterial and antioxidant activity, respectively. The experimental results imply that the cultivation area and climatic conditions of Bulgaria are very suitable for cultivation of S. rebaudiana plants with high content of antioxidants.
\end{abstract}

Keywords: Antimicrobial; antioxidant; methanolic extracts; plant parts; Stevia rebaudiana

\section{ABSTRAK}

Stevia rebaudiana Bertoni adalah spesies tumbuhan yang sering digunakan bukan hanya sebagai pemanis, tetapi juga untuk sifat antibakteria dan antioksidannya. Pada masa kini, terdapat sebilangan besar kajian mengenai aktiviti antimikrob dan antioksidan daun S. rebaudiana, tetapi hampir tidak ada data mengenai potensi antimikrob dan antioksidan ekstrak daripada bahagian lain S. rebaudiana. Tujuan kajian ini adalah untuk menyediakan data potensi antibakteria dan antioksidan ekstrak metanol daripada pelbagai bahagian S. rebaudiana (bunga, daun, batang, rizom dan tuber) yang ditanam di Bulgaria. Aktiviti antibakteria ekstrak terhadap Staphylococcus aureus, Bacillus cereus dan Escherichia coli dinilai dengan kaedah penyebaran agar baik, kandungan rutin - dengan kaedah HPLC, jumlah kandungan fenol dan potensi penyingkiran radikal - dengan analisis UV-Vis. Ekstrak S. rebaudiana menunjukkan aktiviti antibakteria terutamanya terhadap S. aureus - ekstrak bunga menunjukkan aktiviti tertinggi, diikuti oleh ekstrak daun dan batang. Hanya ekstrak bunga dan daun menunjukkan aktiviti antibakteria yang sangat rendah terhadap B. cereus. Ekstrak S. rebaudiana tidak menunjukkan aktiviti antibakteria terhadap E. coli. Ekstrak metanol tumbuhan ini kaya 
dengan antioksidan. Kepekatan tertinggi rutin dan fenol total terdapat pada rizom tanaman, diikuti oleh daun, tuber, bunga dan batang, yang sesuai dengan potensi radikal pencucian pada bahagian tanaman yang sama. Perbandingan antara setara Trolox dan setara asid galik di bahagian yang berlainan di S. rebaudiana di satu pihak, dan setara Trolox dan kepekatan rutin di sisi lain menunjukkan pergantungan positif dan nilai tinggi korelasi Pearson - masing-masing 0,9612 dan 0,9707. Bahagian S. rebaudiana yang paling penting untuk kepentingan perubatan (daun) mempunyai aktiviti antibakteria yang cukup baik dan kandungan antioksidan yang tinggi, walaupun bunga dan rizom masing-masing menunjukkan aktiviti antibakteria dan antioksidan yang lebih tinggi. Hasil uji kaji menunjukkan bahawa kawasan penanaman dan keadaan iklim Bulgaria sangat sesuai untuk penanaman tanaman S. rebaudiana dengan kandungan antioksidan yang tinggi.

Kata kunci: Antimikrob; antioksidan; bahagian tanaman; ekstrak metanol; Stevia rebaudiana

\section{INTRODUCTION}

Stevia rebaudiana Bertoni is a plant species belonging to Stevia genus, which include about 200 species of the sunflower family Asteraceae. It is cultivated in major regions of the world, including Europe, Asia, and North America (Abdel-Rahman et al. 2015). This plant has a wide range of beneficial effects on human and animal health - antibacterial, antimalarial, antifungal, antiviral, anti-asthmatic, anti-inflammatory, hypoglycemic, gastroprotective, antioxidant, nutritional, hypotensive, and anti-cholesterol (Marcinek \& Krejpcio 2016; Zangeneh et al. 2016). The mainly used part of $S$. rebaudiana are the leaves, which are commonly referred to as sugar leaves, candy leaves or sweet leaves. S. rebaudiana leaf extract is frequently used as antimicrobial and a lowcalorie sweetener agent. The sweet properties are due to the steviol glycosides sweetening compounds (mainly stevioside and rebaudioside) (Brandle \& Telmer 2007). At present time stevioside is used as a substitute of sucrose in many industries and has both antimicrobial and antioxidant activity (Pól et al. 2007). The antimicrobial activity of $S$. rebaudiana is due to active compounds such as steviol glycosides, phenols, tannins, flavonoids, and essential oils (Abdel-Rahman et al. 2015; Abou-Arab \& Abou-Salem 2010; Debnath 2008; Lemus-Mondaca et al. 2012; Mali et al. 2015). The study of antimicrobial activity of different plant extracts is very perspective, because they can be used as natural food preservatives or as an alternative to antimicrobial agents, such as antibiotics, which are currently more and more restricted because of the developing microbial resistance following frequent application (Abdel-Rahman et al. 2015; Lemus-Mondaca et al. 2012). Moreover, extracts of beneficial medicinal plants do not have the harmful side effects of many antibiotics (Das et al. 2009).

One of the most important properties of $S$. rebaudiana is the high content of natural antioxidants. Antioxidants are used to preserve food quality mainly through prevention of oxidative deterioration of lipid constituents. The most commonly used antioxidants nowadays are butylated hydroxyanisol (BHA), butylated hydroxytoluene (BHT), propyl gallate (PG) and tetrabutylhydroquinone (TBHQ) (Abou-Arab \& Abou-Salem 2010). However, there is ongoing controversy about the safety of BHA and BHT. They are suspected of being responsible of liver, kidney, lung damage, and carcinogenesis (Grice 1988; Lanigan \& Yamarik 2002). Therefore, the development and utilization of effective antioxidants of natural origin is priority nowadays. Such antioxidants could protect the human and animal body from free radicals and prevent the subsequent oxidative damage, which could induce degenerative and pathological processes, including ageing and cancer (Tadhani et al. 2007). Different studies indicate that $S$. rebaudiana leaves have high antioxidant potential by measuring mainly the radical scavenging activity, phenolic, and flavonoid contents (Abou-Arab \& AbouSalem 2010; Gaweł-Bęben et al. 2015; Grozeva et al. 2015; Khiraoui et al. 2018; Mutmainah et al. 2019). The findings that the chemical constituents of medicinal plants largely depend on several factors such as cultivation area, climatic conditions, vegetation phase and genetic modifications is an important impetus to study medicinal flora present in various growing sites, countries, and geographical zones (Miliauskas et al. 2004). These differences of the chemical constituent's content could 
also lead to variations of antimicrobial activity of the cultivated plants (Das et al. 2009).

Nowadays, there are a lot of studies regarding the antimicrobial and antioxidant activity of $S$. rebaudiana leaves. However, there is a lack of data in the available literature about the antimicrobial and antioxidant potential of extracts from the other parts of $S$. rebaudiana. Exception in this regard is the study of Sunitha et al. (2015), who determined the antimicrobial activity of root, stem, callus, and leaf extracts. This research gap motivated the present study, which aims to compare the antimicrobial and antioxidant activity of $S$. rebaudiana flower, leaf, stem, rhizome, and tuber methanolic extracts. In this way, the practical applicability of these parts of the plant could be evaluated.

\section{MATERIALS AND MeTHODS}

\section{PLANT MATERIAL AND EXTRACT PREPARATION}

The plants for the experiment were harvested in the flowering phase in September, at Malka Vereya village in the region of Stara Zagora, Bulgaria. The soil type is Luvisols with a $\mathrm{pH}$ of 5.6. The climate is transitional continental with influence from Mediterranean Sea. The planting of $S$. rebaudiana was made by plant rhizomes in April. S. rebaudiana was cultivated without fertilization, with a planting density of 80000 plants/ha $(50 / 25 \mathrm{~cm})$. The amount of rainfall during the growing (vegetation) period was lower compared to the norm. The average temperature in April and May was normal for the region, but in June, July, August and September was higher than the norm.

Plant material was air dried in dark at room temperature and grounded in a mechanical grinder (final powder size less than $400 \mu \mathrm{m}$ ). The samples were stored in dark and cool rooms at $16-18{ }^{\circ} \mathrm{C}$ prior to the analysis. The target compounds were extracted by Soxhlet method, at $60{ }^{\circ} \mathrm{C}$, for $8 \mathrm{~h}$. Methanol was used as solvent in the ratio of 1:10 (plant material:solvent). After filtration through $0.45 \mu \mathrm{m}$ membrane, the extracts were concentrated by rotary vacuum evaporator at $30^{\circ} \mathrm{C}$.

\section{TESTED MICROORGANISMS}

In this study were included reference bacterial strains (Staphylococcus aureus ATCC 25923, Escherichia coli ATCC 25922) and a clinical bacterial isolate (Bacillus cereus). The strains were stored at $-20{ }^{\circ} \mathrm{C}$. They were restored on trypticase soy blood agar (Himedia, India) prior to use.

\section{ANTIBACTERIAL ACTIVITY}

Antibacterial activity of the extracts was evaluated by agar well diffusion method described by Velichkova et al. (2018). In brief, inoculums were prepared in saline corresponding to 0.5 of the McFarland standard (1.5 $\times$ $10^{8} \mathrm{CFU} / \mathrm{mL}$ ) from $24 \mathrm{~h}$ bacterial colonies incubated on trypticase soy blood agar. $20 \mathrm{~mL}$ of Mueller Hinton agar (Himedia, India) was poured in every Petri dish. The wells were formed with a sterile $6 \mathrm{~mm}$ cork borer after pre-application of the inoculum with a sterile cotton swab. The wells were filled with $100 \mu \mathrm{L}$ of the extracts. Positive control with gentamicin at a concentration of $12.5 \mu \mathrm{g} / \mathrm{mL}$ and negative with methanol was performed. The plates were incubated at $37^{\circ} \mathrm{C}$ for $24 \mathrm{~h}$ under aerobic conditions.

Antibacterial activity was evaluated by measuring of inhibition zones of microbial growth surrounding the plant extracts in the wells. The zones of inhibition were measured in millimeters. Antibacterial activity was assumed in the presence of a growth inhibition zone $\geq 8.0 \mathrm{~mm}$. The tests were performed in triplicate to determine the reproducibility of the results. The complete experiment was carried out under strict aseptic conditions.

\section{DETERMINATION OF TOTAL PHENOLIC CONTENT (TPC)}

The methanolic extracts were concentrated to final volume of ca $7 \mathrm{~mL}$ by rotary evaporator under vacuum at $30{ }^{\circ} \mathrm{C}$, then transferred into $10 \mathrm{~mL}$ volumetric flask and adjusted with methanol to a final concentration of $0.2 \mathrm{mg} / \mathrm{mL}$. The experimental procedure described by Tzanova et al. (2018) was applied for determination of TPC. In brief, $1 \mathrm{~mL}$ of the methanolic plant extract or $1 \mathrm{~mL}$ standard solution was mixed in separate tubes with 5.0 $\mathrm{mL}$ of Folin-Ciocalteu's reagent (1/10). Then, $4 \mathrm{~mL}$ of 7.5 $\% \mathrm{w} / \mathrm{v} \mathrm{Na}_{2} \mathrm{CO}_{3}$ was added and the tubes were left at room temperature for $60 \mathrm{~min}$. The absorbance at $765 \mathrm{~nm}$ was measured against water on a Thermo Scientific Evolution 300 spectrophotometer. Each sample was analyzed in triplicate. Gallic acid (Sigma-Aldrich, St. Louis, MO) solutions in methanol ranging from 2 to $20 \mu \mathrm{g} / \mathrm{mL}$ were used for calibration curve $\left(\mathrm{R}^{2}=0.9988\right)$. TPC of each sample was expressed as grams gallic acid equivalents (GAE) in $1 \mathrm{~kg}$ dry matter (dm) of plant extract. 


\section{RUTIN DETERMINATION}

The rutin levels in methanolic extracts were determined by HPLC analysis developed and validated by Ashokkumar et al. (2013). The volume of each extract sample was adjusted to $25 \mathrm{~mL}$ with methanol. The solutions were stored overnight at $-12{ }^{\circ} \mathrm{C}$ prior to the HPLC analysis.

Analytical HPLC was performed with a $\mathrm{C} 18$ column Hypersil Gold $(5 \mu \mathrm{m} ; 150 \mathrm{~mm} \times 4.6 \mathrm{~mm})$ on a Thermo system: Surveyor LC Pump Plus, Surveyor Autosampler Plus, and Surveyor photodiode array detector PDA Plus. Quantitative analysis was performed in a 6-min run, isocratic mode at a flow rate of $0.8 \mathrm{~mL} / \mathrm{min}$ of the eluent: methanol/acetonitrile/water/acetic acid $(40+20+39+1, \mathrm{v} / \mathrm{v} / \mathrm{v} / \mathrm{v})$. The rutin was identified using UV absorbance at $254 \mathrm{~nm}$. The external calibration was carried out using five concentration levels $(0.05,0.5,1.0$, 2.0 and $5.0 \mathrm{mg} / \mathrm{L}$ ) of reference material - rutin hydrate ( $\mathrm{min}$ $94 \%$, HPLC, from Sigma-Aldrich, St. Louis, MO). Each standard solution was run in triplicate. The correlation coefficients $\left(\mathrm{r}^{2}\right)$ obtained by linear regression of 0.9991 demonstrated an excellent relationship between peak area and concentration according to the International Council for Harmonization (ICH) guidelines (1997).

\section{DETERMINATION OF RADICAL SCAVENGING ACTIVITY BY DPPH METHOD}

The method described by Tzanova et al. (2018) was applied to measure radical scavenging potential of methanolic extracts obtained from different plant parts of $S$. rebaudeana. In brief, to $2 \mathrm{~mL}$ of $100 \mathrm{M}$ solution of DPPH in methanol was added $20 \mu \mathrm{L}$ of methanolic extract $(1 \mathrm{mg} / \mathrm{mL})$. Two parallel samples of each extract were analyzed. Absorption at $517 \mathrm{~nm}$ was measured on a Thermo Scientific Evolution 300 spectrophotometer $30 \mathrm{~min}$ later. Since the composition of the extracts is complex, the results for their radical scavenging capacity were compared with Trolox and calculated by regression analysis from the linear dependence between concentration of Trolox and absorption at $517 \mathrm{~nm}$. The results were expressed as mmol Trolox equivalent (TE) in $1 \mathrm{~kg} \mathrm{dm}$ of plant extract.

\section{STATISTICAL ANALYSIS}

All analytical assays were carried out in triplicate and expressed as mean values \pm standard deviation (SD).
Statistical analysis was performed with Statistica 10, StatSoft Inc.

\section{RESULTS AND DISCUSSION}

Stevia rebaudiana Bertoni is a popular medicinal plant, which components are mainly used as sweeteners. Studies of plant extracts with antimicrobial and antioxidant activity have been increasing over the last decade. There are various experiments concerning the antimicrobial activities of $S$. rebaudiana leaf extracts, but a data about the antibacterial activity of the other parts of this plant is still limited. The only exception is the research of Sunitha et al. (2015), who studied the antimicrobial activity of methanolic and ethanolic extracts of stems, roots, calluses, and leaves. Because of the major differences of the type of solvents and the concentrations of $S$. rebaudiana leaf extracts reported by various authors, a few studies could be used to compare the result of this experiment. Concerning the use of different solvents, methanol was found to be one of the best solvents of $S$. rebaudiana resulting in high antimicrobial and antioxidant activity (Abdel-Rahman et al. 2015; Darshana \& Aruna 2017; Debnath 2008; Gupta et al. 2017).

According to the experimental data (Table 1), $S$. rebaudiana methanolic extracts had antibacterial activity mainly against $S$. aureus, and the highest activity measured in diameter of inhibition zones (mean \pm SD) was demonstrated by flower extracts (13.9 \pm 0.3$)$, followed by the leaf $(10.0 \pm 0.4)$ and stem $(8.25 \pm 0.5)$ extracts and the differences with negative control (methanol) values were statistically significant $(\mathrm{P} \leq 0.05)$. Only flower and leaf extracts showed reliable antibacterial activity against $S$. aureus (active even at 8 $\mathrm{mg} / \mathrm{mL}$ ), while the activity of stem extracts was not high enough. Rhizome and tuber extracts did not express any activity against $S$. aureus.

The activity of leaf extracts was higher than the activity reported by Abdel-Rahman et al. (2015) - $8 \mathrm{~mm}$, Mali et al. (2015) - $8 \mathrm{~mm}$, Tadhani and Subhash (2006) - $8.33 \mathrm{~mm}$, Debnath (2008) - $9 \mathrm{~mm}$, but lower than the findings of Abou-Arab and Abu-Salem (2010) - 16 mm. On the other hand, Sunitha et al. (2015) reported a lack of antibacterial activity of $S$. rebaudiana leaf extracts against $S$. aureus but low activity of stem extracts (9 $\mathrm{mm}$ ), which is unlike the results of this study. As a whole, methanolic extracts of $S$. rebaudiana cultivated in Bulgaria demonstrated good activity against $S$. aureus. 
TABLE 1. Diameter of inhibition zones $(\mathrm{mm})$ of methanolic extracts from Stevia rebaudiana Bertoni (mean $\pm \mathrm{SD})$

\begin{tabular}{|c|c|c|c|c|}
\hline Plant parts & Methanolic extracts $(\mathrm{mg} / \mathrm{mL})$ & S. aureus & E. coli & B. cereus \\
\hline \multirow{4}{*}{ Leaves } & 32 & $10.0 \pm 0.4^{\mathrm{ab} *}$ & - & $7.3 \pm 0.5^{\mathrm{a}}$ \\
\hline & 16 & $9.0 \pm 0^{\mathrm{ab}}$ & - & - \\
\hline & 8 & $8.0 \pm 0^{\mathrm{ab}}$ & - & - \\
\hline & 4 & - & - & - \\
\hline \multirow{5}{*}{ Flowers } & 32 & $13.9 \pm 0.3^{\mathrm{ab}}$ & - & $8.0 \pm 0.8^{\mathrm{a}}$ \\
\hline & 16 & $10.6 \pm 0.5^{\mathrm{ab}}$ & & \\
\hline & 8 & $9.0 \pm 0^{\mathrm{ab}}$ & & \\
\hline & 4 & $7.25 \pm 0.95^{\mathrm{a}}$ & & \\
\hline & 2 & - & & \\
\hline Stems & 32 & $8.25 \pm 0.5^{\mathrm{ab}}$ & - & - \\
\hline Rhizomes & 32 & - & - & - \\
\hline Tubers & 32 & $7.25 \pm 0.95^{\mathrm{a}}$ & - & - \\
\hline Methanol & 0 & $7.0 \pm 0^{\mathrm{a}}$ & $7.0 \pm 0^{\mathrm{a}}$ & $6.0 \pm 0^{\mathrm{a}}$ \\
\hline Gentamicin & $12.5 \mu \mathrm{g} / \mathrm{mL}$ & $21.0 \pm 0$ & $17.0 \pm 0$ & $23.0 \pm 0$ \\
\hline
\end{tabular}

Only the flower and leaf extracts had antibacterial activity against $B$. cereus, which however was very low $(8.0 \pm 0.8$ and $7.3 \pm 0.5$, respectively) and the differences with negative control values were not statistically significant (Table 1). The activity of the leaf extracts was lower than the experimental results of Abdel-Rahman et al. (2015) - $9 \mathrm{~mm}$, and especially of Abou-Arab and Abu-Salem (2010) - 25 mm.

Methanolic extracts from $S$. rebaudiana did not show any antibacterial activity against E. coli (Table $1)$. These results are similar to the findings of AbdelRahman et al. (2015), Abou-Arab and Abu-Salem (2010), and Das et al. (2009). However, Mali et al. (2015) and Gupta et al. (2017) reported relatively large zones of inhibition of $S$. rebaudiana leaf extracts against $E$. coli $11.8 \mathrm{~mm}$ and $13.15 \mathrm{~mm}$, respectively. Low antibacterial activity of leaf extracts against $E$. coli was found by
Tadhani and Subhash (2006) - $8.67 \mathrm{~mm}$. Sunitha et al. (2015) also reported low efficacy of leaf extracts against E. coli $(8.16 \mathrm{~mm})$, which was even lesser than the activity of stem extracts $(8.25 \mathrm{~mm})$. The differences in the zones of inhibition of $S$. aureus, B. cereus, and $E$. coli in this study and the other experiments could be due to various reasons - cultivation area, climatic conditions, bacterial strains, and method of extract preparation. Due to these differences, only the general trends of the antimicrobial activity of $S$. rebaudiana leaf extracts could be found.

The inhibition zones of the positive control $(12.5 \mu \mathrm{g} /$ $\mathrm{mL}$ gentamicin) for $S$. aureus, E. coli, and B. cereus were 21, 17, and $23 \mathrm{~mm}$, respectively, which means that all microorganisms were sensitive to positive control.

Phenolic compounds are a large class of plant secondary metabolites, demonstrating a variety of structures, from rather simple structures, e.g. phenolic 
acids, through polyphenols such as flavonoids, to polymeric compounds based on the different classes (Cheynier 2012). Phenolic compounds derived from natural sources have been related to various health benefits including antioxidant, anti-aging, anti-inflammatory, anti-proliferative, and antimicrobial activities (AbouArab \& Abu-Salem 2010; Lin et al. 2016). According to the results of this study, methanolic extracts from $S$. rebaudiana cultivated in Bulgaria are rich in antioxidants and the highest concentrations (mean $\pm \mathrm{SD}$ ) of TPC ( $g$ GAE $/ \mathrm{kg}$ ) were found in the rhizomes of the plants (426 \pm 128$)$, followed in descending gradation by the leaves (354 \pm 82$)$, tubers $(266 \pm 60)$, flowers $(167 \pm 27)$ and stems (59 \pm 26$)$ (Figure 1).

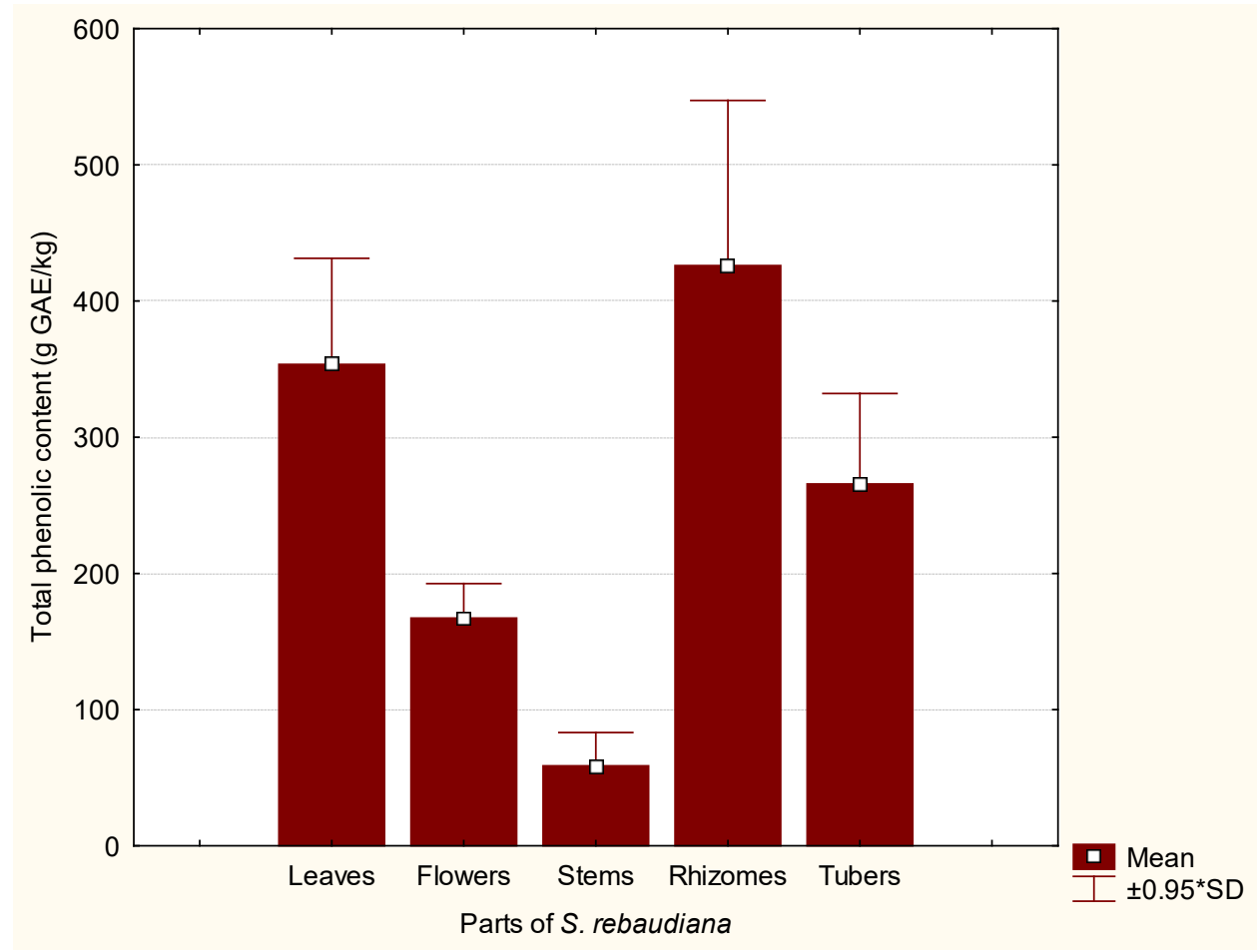

FIGURE 1. Total phenolic content (g GAE $/ \mathrm{kg}$ ) in different parts of Stevia rebaudiana

TPC of S. rebaudiana leaves was much higher than the results obtained by Shivanna et al. (2013) - $91.0 \mathrm{~g}$ GAE/kg, Covarrubias-Cárdenas et al. (2018) - 71.76 g GAE $/ \mathrm{kg}$, Khiraoui et al. (2018) - $25.39-43.45 \mathrm{~g} \mathrm{GAE} /$ $\mathrm{kg}$, Jahan et al. (2010) - $31.25 \mathrm{~g} \mathrm{GAE} / \mathrm{kg}$, Mutmainah et al. (2019) - $24.73 \mathrm{~g} \mathrm{GAE} / \mathrm{kg}$, Abou-Arab and AbuSalem (2010) - $10.77 \mathrm{~g}$ GAE $/ \mathrm{kg}$. These differences could be partially due to the method of extract preparation, including type of solvents, and different time for extract preparation. In this respect, some authors found a high impact of the particle size of ground S. rebaudiana leaves, the type of solvents and different drying methods on the quantity of antioxidants and the antioxidant potential of $S$. rebaudiana leaf extracts as a whole (Grozeva et al. 2015; Lemus-Mondaca et al. 2018; Moguel-Ordóñez et al. 2015). The cultivation area and climatic conditions also influence the quantity of antioxidants - the mentioned plants for extract preparation were harvested in Egypt 
(Abou-Arab \& Abou-Salem 2010), India (Shivanna et al. 2013), Mexico (Covarrubias-Cárdenas et al. 2018), Morocco (Khiraoui et al. 2018), and Bangladesh (Jahan et al. 2010).

Flavonoids are reputed to be a unique class of molecules due to their therapeutic properties. From these advantages, rutin, also known as vitamin $\mathrm{P}$ or rutoside, has been explored for a number of pharmacological activities, including antioxidant, cytoprotective, vasoprotective, anticarcinogenic, neuroprotective, and cardioprotective activities (Ganeshpurkar \& Saluja 2017). Rutin content (g/kg) in $S$. rebaudiana parts was corresponding to TPC (g GAE $/ \mathrm{kg}$ ) and the highest concentrations (mean \pm SD) were found again in the rhizomes of the plants (14.5 \pm 3.2$)$, followed in descending order by the leaves $(12.2 \pm 2.5)$, tubers $(8.4 \pm 1.0)$, flowers

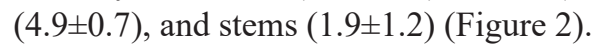

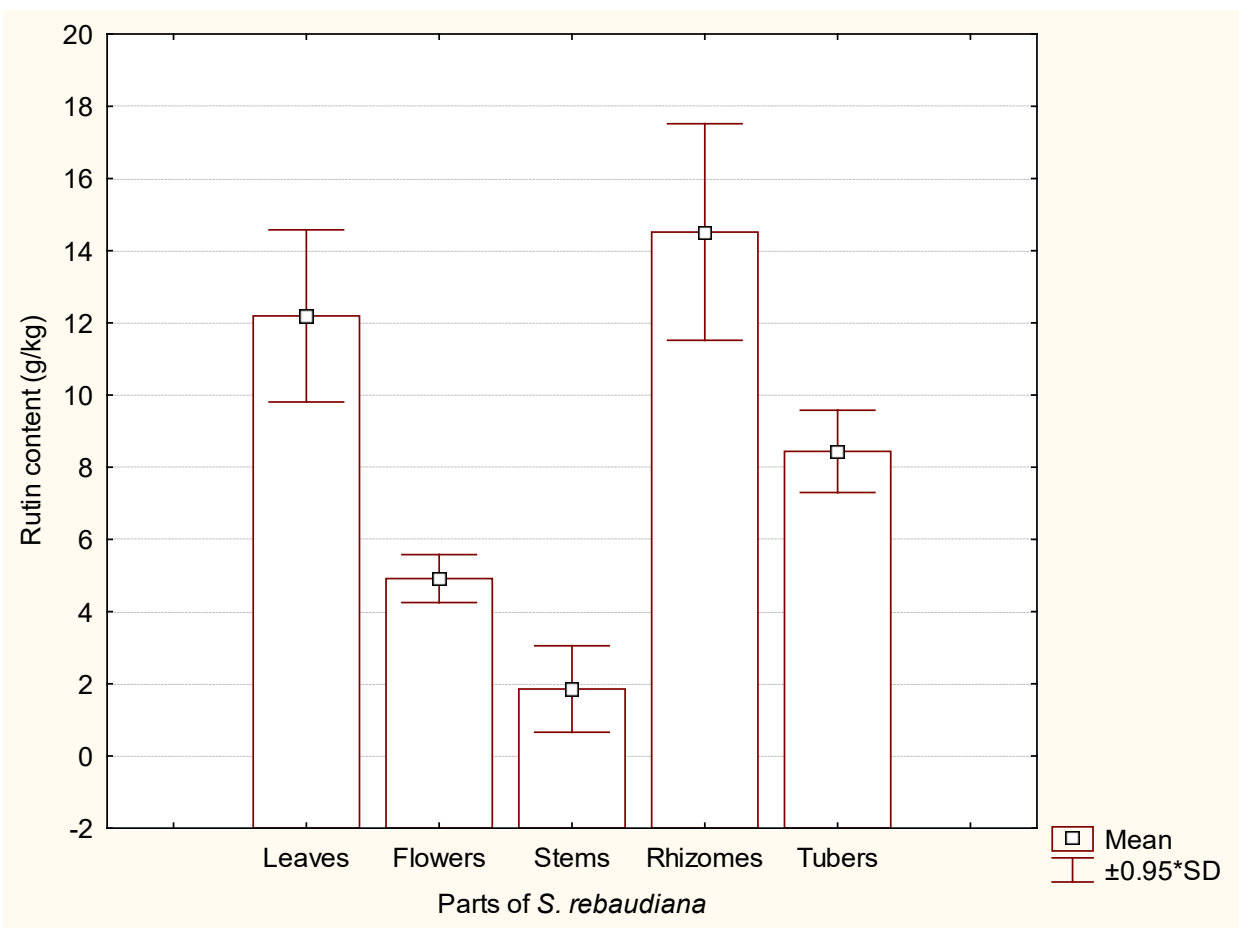

FIGURE 2. Rutin content $(\mathrm{g} / \mathrm{kg})$ in different parts of Stevia rebaudiana

The rutin content of $S$. rebaudiana leaves from Bulgarian plants was higher than the concentrations in Mexican plants $(3.05 \mathrm{~g} / \mathrm{kg}$ ) (Covarrubias-Cárdenas et al. 2018). The differences could also be due to the method of extract preparation and the type of solvents. The available literature lacks enough data about the content of different flavonoids and rutin in particular in $S$. rebaudiana leaves. The different methods for determination of rutin concentration make a comparison even more difficult. The parallel between our results and the different literature data about the rutin and total phenolic concentrations imply that the cultivation area and climatic conditions of Bulgaria are very suitable for cultivation of $S$. rebaudiana plants with high content of antioxidants.

There are many different antioxidants presented in plants, therefore, it is very difficult to measure each antioxidant component separately. DPPH radicals are 
widely used as a model system to evaluate the scavenging activities of the natural antioxidant compounds (Zayova et al. 2013). The radical scavenging potential (mmol TE/ $\mathrm{kg}$ ) of $S$. rebaudiana plant parts corresponded to TPC and rutin content in rhizomes, leaves, tubers, flowers, and stems and was $357 \pm 47,297 \pm 33,246 \pm 45,144 \pm 12,53 \pm 7$, respectively (mean $\pm \mathrm{SD}$, Figure 3 ).

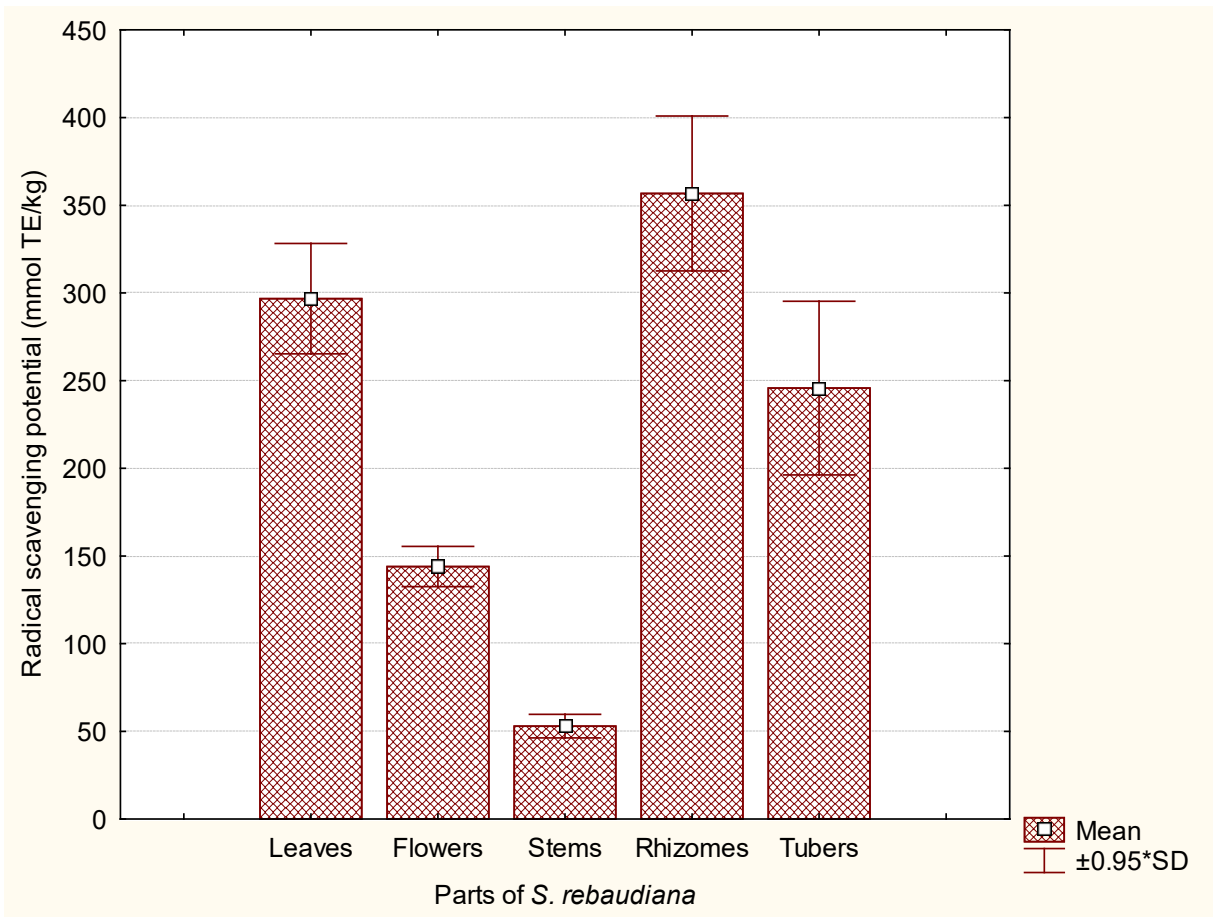

FIGURE 3. Radical scavenging potential ( $\mathrm{mmol} \mathrm{TE} / \mathrm{kg})$ in different parts of Stevia rebaudiana

The radical scavenging potential of $S$. rebaudiana leaves cultivated in Bulgaria is significantly lower than the activity reported by Covarrubias-Cárdenas et al. (2018) - $517 \mathrm{mmol} \mathrm{TE} / \mathrm{kg}$, who however, presented lower levels of TPC and rutin than obtained in this study. The difference in both investigations could be due to the different content of non-phenolic antioxidant compounds in $S$. rebaudiana leaves, as well as the different methods of determination of radical scavenging activity. Different researchers used a different method of the determination of $S$. rebaudiana radical scavenging potential, therefore, it is difficult to compare the results of this experiment regarding the radical scavenging potential with the literature data.

Comparisons between Trolox equivalents and gallic acid equivalents in different parts of $S$. rebaudiana on one hand, and Trolox equivalents and rutin concentration on the other hand showed high correlations (Figure 4). The established Pearson correlation expressed a positive dependence with high correlation coefficients: 0.9612 and 0.9707, respectively. Most likely, phenolic compounds, including flavonoids such as rutin, presented in different plant organs are the main constituents responsible for the high antioxidant activity of $S$. rebaudiana. 


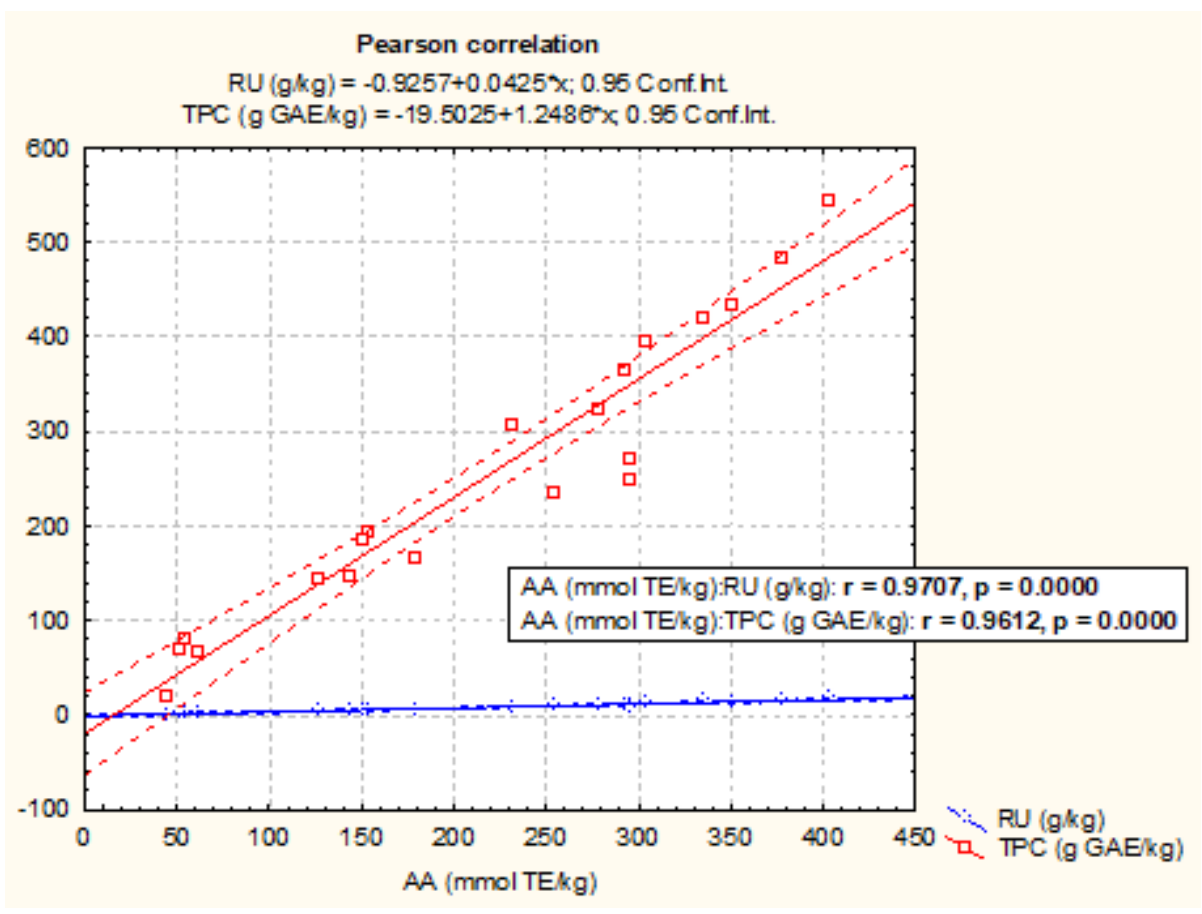

FIGURE 4. Pearson correlation between radical scavenging potential and rutin content; and radical scavenging potential and total phenolic content of Stevia rebaudiana, $\mathrm{P} \leq 0.01$ (2-tailed)

\section{CONCLUSION}

Methanolic extracts of $S$. rebaudiana cultivated in Bulgaria showed antibacterial activity mainly against $S$. aureus. Flower extracts expressed the highest activity, followed by the leaf and stem extracts. The flower and leaf extracts demonstrated very low antibacterial activity against $B$. cereus. Extracts from $S$. rebaudiana did not show any antibacterial activity against $E$. coli. Methanolic extracts from $S$. rebaudiana are rich in antioxidants and the highest concentrations of rutin and TPC were found in the rhizomes of the plants, followed in descending gradation by the leaves, tubers, flowers, and stems which corresponded to the radical scavenging potential of the same plant part. It is important to emphasize that the part of $S$. rebaudiana with medicinal significance (the leaves) has both comparatively good antibacterial activity and high content of antioxidants, although the flowers and rhizomes expressed higher antibacterial and antioxidant activity, respectively. The experimental results indicate that the cultivation area and climatic conditions of Bulgaria are very suitable for cultivation of $S$. rebaudiana plants with high antioxidant content.

\section{ACKNOWLEDGEMENTS}

This work was supported by the Bulgarian Ministry of Education and Science under the National Research Programme 'Healthy Foods for a Strong Bio-Economy and Quality of Life' approved by DCM \#577/17.08.2018.

\section{REFERENCES}

Abdel-Rahman, T., Abdelwahed, M., El-Ela Elsaid, M. \& El-Beih, A. 2015. Free calorie sweetness and antimicrobial properties in Stevia rebaudiana. Research Journal of Pharmaceutical, Biological and Chemical Sciences 6(5): 669-679.

Abou-Arab, E. \& Abu-Salem, F. 2010. Evaluation of bioactive compounds of Stevia rebaudiana leaves and callus. African Journal of Food Science 4(10): 627-634. 
Ashokkumar, K., Selvaraj, K. \& Saradha Devi, K. 2013. Reverse phase-high performance liquid chromatographydiode array detector (RP-HPLC-DAD) analysis of flavonoids profile from curry leaf (Murraya koenigii L.). Journal of Medicinal Plant Research 7(47): 3393-3399.

Brandle, J. \& Telmer, P. 2007. Steviol glycoside biosynthesis. Phytochemistry 68(14): 1855-1863.

Cheynier, V. 2012. Phenolic compounds: From plants to foods. Phytochemistry Reviews 11: 153-177.

Covarrubias-Cárdenas, A., Martínez-Castillo, J., Medina-Torres, N., Ayora-Talavera, T., Espinosa-Andrews, H., García-Cruz, N. \& Pacheco, N. 2018. Antioxidant activity and UPLCPDA ESI-MS phenolic profile of Stevia rebaudiana dry powder extracts obtained by ultrasound assisted extraction. Agronomy 8: 170.

Darshana, R. \& Aruna, K. 2017. Antimicrobial activity of Stevia rebaudiana against antibiotic resistant ESBL producing uropathogens and evaluation of its antioxidant activity. International Journal of Advanced Research in Biological Sciences 4(3): 110-118.

Das, K., Dang, R. \& Gupta, N. 2009. Comparative antimicrobial potential of different extracts of leaves of Stevia rebaudiana Bert. International Journal of Natural and Engeneering Sciences 3(1): 65-68.

Debnath, M. 2008. Clonal propagation and antimicrobial activity of an endemic medicinal plant Stevia rebaudiana. Journal of Medicinal Plants Research 2(2): 45-51.

Ganeshpurkar, A. \& Saluja, A. 2017. The pharmacological potential of rutin. Saudi Pharmaceutical Journal 25(2): 149-164.

Gaweł-Bęben, K., Bujak, T., Nizioł-Łukaszewska, Z., Antosiewisz, B., Jakubczyk, A., Karaś, M. \& Rybczyńska, K. 2015. Stevia rebaudiana Bert. leaf extracts as a multifunctional source of natural antioxidants. Molecules 20: 5468-5486.

Grice, H. 1988. Safety evaluation of butylated hydroxyanisole from the perspective of effects on forestomach and oesophageal squamous epithelium. Food and Chemical Toxicology 26(8): 717-723.

Grozeva, N., Pavlov, D., Petkova, N., Ivanov, I., Denev, P., Pavlov, A., Gerdzhikova, M. \& Dimanova-Rudolf, M. 2015. Characterisation of extracts from Stevia rebaudiana Bertoni leaves. International Journal of Pharmacognosy and Phytochemical Research 7(6): 1236-1243.

Gupta, E., Vajpayee, G., Purwar, S., Shakyawar, S., Alok, S. \& Sundaram, S. 2017. Phytochemical screening and in-vitro studies of antioxidant and antimicrobial activity of extracts of dried Stevia rebaudiana leaves. International Journal of Pharmaceutical Sciences and Research 8(8): 3354-3360.

ICH Guidelines. 1997. Validation of Analytical Procedures: Methodology. Q2B, FDA, Federal Register.

Jahan, I., Mostafa, M., Hossain, H., Nimmi, I., Sattar, A., Alim, A. \& Moeiz, S. 2010. Antioxidant activity of Stevia rebaudiana Bert. leaves from Bangladesh. Bangladesh Pharmaceutical Journal 13(2): 67-75.

Khiraoui, A., Al Faiz, C., Hasib, A., Bakha, M., Benhmimou, A., Amchra, F. \& Boulli, A. 2018. Antioxidant ability, total phenolic and flavonoid contents of leaf extract of Stevia rebaudiana Bertoni cultivated in Morocco. International Journal of Scientific \& Engeneering Research 9(5): 15851590.

Lanigan, R. \& Yamarik, T. 2002. Final report of the safety assessment of BHT. International Journal of Toxicology 21(Suppl. 2): 19-94.

Lemus-Mondaca, R., Vega-Gálvez, A., Rojas, P., Stucken, K., Delporte, C., Valenzuela-Barra, G., Jagus, |R., Agüero, M. \& Pasten, A. 2018. Antioxidant, antimicrobial and antiinflammatory potential of Stevia rebaudiana leaves: Effect of different drying methods. Journal of Applied Research on Medicinal and Aromatic Plants 11:37-46.

Lemus-Mondaca, R., Vega-Gálvez, A., Zura-Bravo, L. \& Ah-Hen, K. 2012. Stevia rebaudiana Bertoni, source of a high-potency natural sweetener: A comprehensive review on the biochemical, nutritional and functional aspects. Food Chemistry 132: 1121-1132.

Lin, D., Xiao, M., Zhao, J., Li, Z., Xing, B., Li, H., Kong, M., Li, L., Zhang, Q., Liu, Y., Chen, H., Qin, W., Wu, H. \& Chen, S. 2016. An overview of plant phenolic compounds and their importance in human nutrition and management of type 2 diabetes. Molecules 21(10): 1374.

Mali, A., Joshi, M. \& Kulkarni, V. 2015. Phytochemical screening and antimicrobial activity of Stevia rebaudiana leaves. International Journal of Current Microbiology and Applied Sciences 4(10): 678-685.

Marcinek, K. \& Krejpcio, Z. 2016. Stevia rebaudiana Bertoni: Health promoting properties and therapeutic applications. Journal of Consumer Protection and Food Safety 11: 3-8.

Miliauskas, G., Venskutonis, P. \& van Beek, T. 2004. Screening of radical scavenging activity of some medicinal and aromatic plant extracts. Food Chemistry 85: 231-237.

Moguel-Ordóñez, Y., Cabrera-Amaro, D., Segura-Campos, M. \& Ruiz-Ruiz, J. 2015. Studies on drying characteristic, nutritional composition, and antioxidant properties of Stevia rebaudiana (Bertoni) leaves. International Agrophysics 29: 323-331.

Mutmainah, Kusmita, L., Martono, Y., Franyoto, Y., Wulandari, R. \& Kusumaningrum, T. 2019. Antioxidant activity, phenol and flavonoid content, and formulation cream of Stevia rebaudiana Bert. Journal of Physics: Conference Series 1217: 012152.

Pól, J., Hohnová, B. \& Hyötyläinen, T. 2007. Characterisation of Stevia rebaudiana by comprehensive two-dimensional chromatography time-of-flight mass spectrometry. Journal of Chromatography A 1150(1-2): 85-92. 
Shivanna, N., Naika, M., Khanum, F. \& Kaul, V. 2013. Antioxidant, anti-diabetic and renal properties of Stevia rebaudiana. Journal of Diabetes and its Complications 27: 103-113.

Sunitha, V., Irene, J. \& Reginold, M. 2015. Antibacterial activity in medicinal plant (Stevia rebaudiana) using two solvents. International Journal of Recent Scientific Research 6(7): 5070-5071.

Tadhani, M. \& Subhash, R. 2006. In vitro antimicrobial activity of Stevia rebaudiana Bertoni leaves. Tropical Journal of Pharmaceutical Research 5(1): 557-560.

Tadhani, M., Patel, V. \& Subhash, V. 2007. In vitro antioxidant activities of Stevia rebaudiana leaves and callus. Journal of Food Composition and Analysis 20: 323-329.

Tzanova, M., Grozeva, N., Gerdzhikova, M., Argirova, M., Pavlov, D. \& Terzieva, S. 2018. Flavonoid content and antioxidant activity of Betonica bulgarica Degen et Neič. Bulgarian Chemical Communications 50(C): 90-97.

Velichkova, K., Sirakov, I., Rusenova, N., Beev, G., Denev, S., Valcheva, N. \& Dinev, T. 2018. In vitro antimicrobial activity on Lemna minuta, Chlorella vulgaris and Spirulina sp. extracts. Fresenius Environmental Bulletin 27(8): 57365741.

Zangeneh, M., Najafi, F., Tahvilian, R., Haghnazari, L., Zangeneh, A., Abiari, M. \& Moradi, R. 2016. Study on the in vitro antibacterial properties of alcoholic extract of Stevia rebaudiana in west of Iran. International Journal of Scientific \& Engineering Research 7(11): 1352-1359.

Zayova, E., Stancheva, I., Geneva, M., Petrova, M. \& Dimitrova, L. 2013. Antioxidant activity of in vitro propagated Stevia rebaudiana Bertoni plants of different origins. Turkish Journal of Biology 37: 106-113.
Toncho Dinev*, Milena Tzanova \& Georgi Beev Department of Biochemistry, Microbiology and Physics Faculty of Agriculture

Trakia University 6000 Stara Zagora

Bulgaria

Nikolina Rusenova

Department of Veterinary Microbiology

Infectious and Parasitic Diseases

Faculty of Veterinary Medicine

Trakia University

6000 Stara Zagora

Bulgaria

\section{Neli Grozeva}

Department of Biology and Aquaculture

Faculty of Agriculture

Trakia University

6000 Stara Zagora

Bulgaria

\section{Mariya Gerdzhikova}

Department of Plant Production

Faculty of Agriculture

Trakia University

6000 Stara Zagora

Bulgaria

*Corresponding author; email: dinev_sz@mail.bg

Received: 13 October 2020

Accepted: 30 January 2021 